\title{
Neurological Complication Leading to Mortality After CyberKnife Radiosurgery for Hypothalamic Hamartoma
}

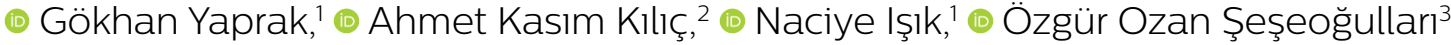

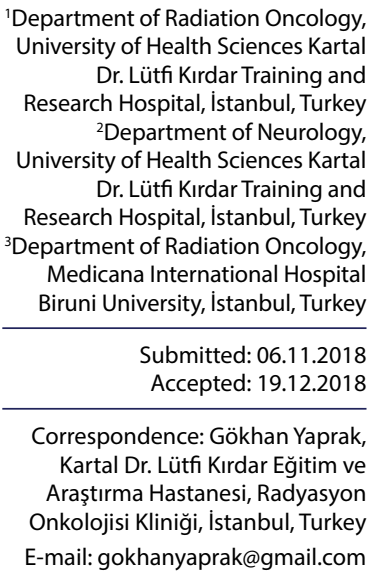

Submitted: 06.11.2018 Accepted: 19.12.2018

Correspondence: Gökhan Yaprak, Kartal Dr. Lütfi Kırdar Eğitim ve Araştırma Hastanesi, Radyasyon Onkolojisi Kliniği, İstanbul, Turkey E-mail: gokhanyaprak@gmail.com

\begin{abstract}
Hypothalamic hamartomas $(\mathrm{HHs})$ are congenital abnormalities. They are mostly marked by epileptic seizures and shown in epileptogenesis. Stereotactic radiosurgery (RS), microsurgical resection, endoscopic disconnection, and stereotactic radiofrequency thermocoagulation are considered as treatment options. Here we present a case of a patient with $\mathrm{HH}$ who was treated by CyberKnife RS and had a fatal course.
\end{abstract}

\section{INTRODUCTION}

Hypothalamic region hamartomas are known as non-neoplastic congenital abnormalities of the gray matter. They consist of disordered clustering of mature neurons, glia, and fibers. ${ }^{[1]}$ Prevalence rates were reported to be $1-2$ cases $/ 100,000$ in children and adolescents. ${ }^{[2]}$ Patients have intractable epileptic seizures mostly with gelastic seizures, learning disability, behavioral issues, and endocrinological abnormalities. [3] Hypothalamic hamartomas $(\mathrm{HHs})$ can be treated by radiosurgery (RS) as a safe and effective option. Hamartomas are characterized by epileptic seizures or serious behavioral disorders. ${ }^{[4,5]}$ Sufficient symptomatic control can be achieved following RS treatment. ${ }^{[5,6]}$ Tumor size reduction, adjacent edema related to non-necrotizing radio-induced inflammatory reactions, or side effects are rarely seen. ${ }^{[5,6]}$

\section{CASE REPORT}

A 22-year-old male patient was admitted to our center with subacute onset of right-sided ptosis and generalized tonic- clonic convulsive epileptic seizures. His routine biochemi$\mathrm{cal}$ and serological tests were negative. He had no learning disability, endocrinological abnormalities, or any finding of a syndromic component. Cranial magnetic resonance imaging (MRI) revealed a homogenous mass lesion of $10 \times 8 \mathrm{~mm}$ size that caused mild obstruction in the aqueductus sylvii and mild dilatation in the third and lateral ventricles. In addition, the lesion showed gadolinium enhancing peripherally. Lesion type was mostly consistent with Type III HH. ${ }^{[4]}$ Magnetic resonance spectroscopy findings on the region of the lesion were as follows: $\mathrm{N}$-acetylaspartate (NAA) decrease, NAA/creatinine ratio decrease, prominent choline increase, and mild lipid and lactate increase. These findings were in accordance with neoplastic origin. Intracranial biopsy could not be performed due to the patient' decision. When evaluated for epileptic seizures, a gelastic component could not be found in his seizure semiology. Seizures were an as generalized tonic-clonic type and could not be controlled with levetiracetam monotherapy. In spite of adding other antiepileptic drugs (oxcarbazepine and zonisamide), adequate seizure control cannot be achieved. 
CyberKnife treatment protocol was planned, and a total of $15 \mathrm{~Gy}$ to the $76 \%$ isodose line have been received by the patient. Dexamethasone $8 \mathrm{mg} 2 \times 1 /$ day with tapering dose was given for edema control for 5 days. Two months after RS, he presented with drowsiness, fever, and decreased the level of consciousness as a direct effect on hypothalamic edema secondary to RS. MRI revealed bilateral and symmetric edema, suggesting radiological changes secondary to the non-necrotizing radio-induced inflammatory reaction in the hypothalamic region. In addition, obstructive triventricular hydrocephalus was observed (Fig. I). A highdose dexamethasone treatment ( $1.5 \mathrm{mg} / \mathrm{kg} /$ day for 5 days) was initiated again, and the neurosurgery department was consulted. The patient was lost to follow-up at this point, and after a 3-month period, it has been learned that the patient had ended treatment by himself and started to use some herbal extracts. Although there was certain control of seizure recurrence, the patient died due to intracranial complications.

\section{DISCUSSION}

HHs mostly presents itself with epileptic seizures. ${ }^{[4]}$ Generally, gelastic attacks typically are referred as HHs. In addition, other seizure types as generalized tonic-clonic, complex partial, or absence can be seen. ${ }^{[4]}$ Other symptoms, such as learning difficulties, psychiatric symptoms, endocrinological abnormalities, or central precocious puberty, can accompany $\mathrm{HH}^{\left[{ }^{[4]}\right.}$ Our patient had only generalized tonic-clonic seizure type, and it was not controlled effectively with levetiracetam. Stereotactic RS is a neurosurgical procedure in treating $\mathrm{HHs}$ with refractory symptoms. ${ }^{[1]}$ RS technique is established and the most commonly used treatment option. ${ }^{\left[{ }^{[}\right]}$Particularly, small, deeply located lesions may have a chance because of its precision and safety. ${ }^{\left[{ }^{1]}\right.}$ In this method, ionizing radiation is used to stereotactically focus on the predetermined target, with minimal radiation effect to the surrounding tissues. ${ }^{\left[{ }^{[}\right]}$

$\mathrm{RS}$ in $\mathrm{HH}$ treatment has been also recommended in guidelines. $^{[3]}$ It was shown that GK doses $>17$ Gy were used in all patients who became seizure-free, but doses $<13$ Gy were not associated with seizure freedom. ${ }^{[7]}$ These patients mostly have intractable seizures, and seizure control rates were reported to be up to $66 \% .{ }^{[4]}$ In a study consisting of 57 children and adults, follow-up of 48 patients showed gamma knife RS efficacious at seizure control Engel I and II levels in 30/48 patients. ${ }^{[5]}$ In addition, no cognitive worsening or endocrinological abnormalities were reported. ${ }^{[5]}$ In 48 patients, 17 were Type III HH as in our case in this study. ${ }^{[5]}$ Another study comparing en-
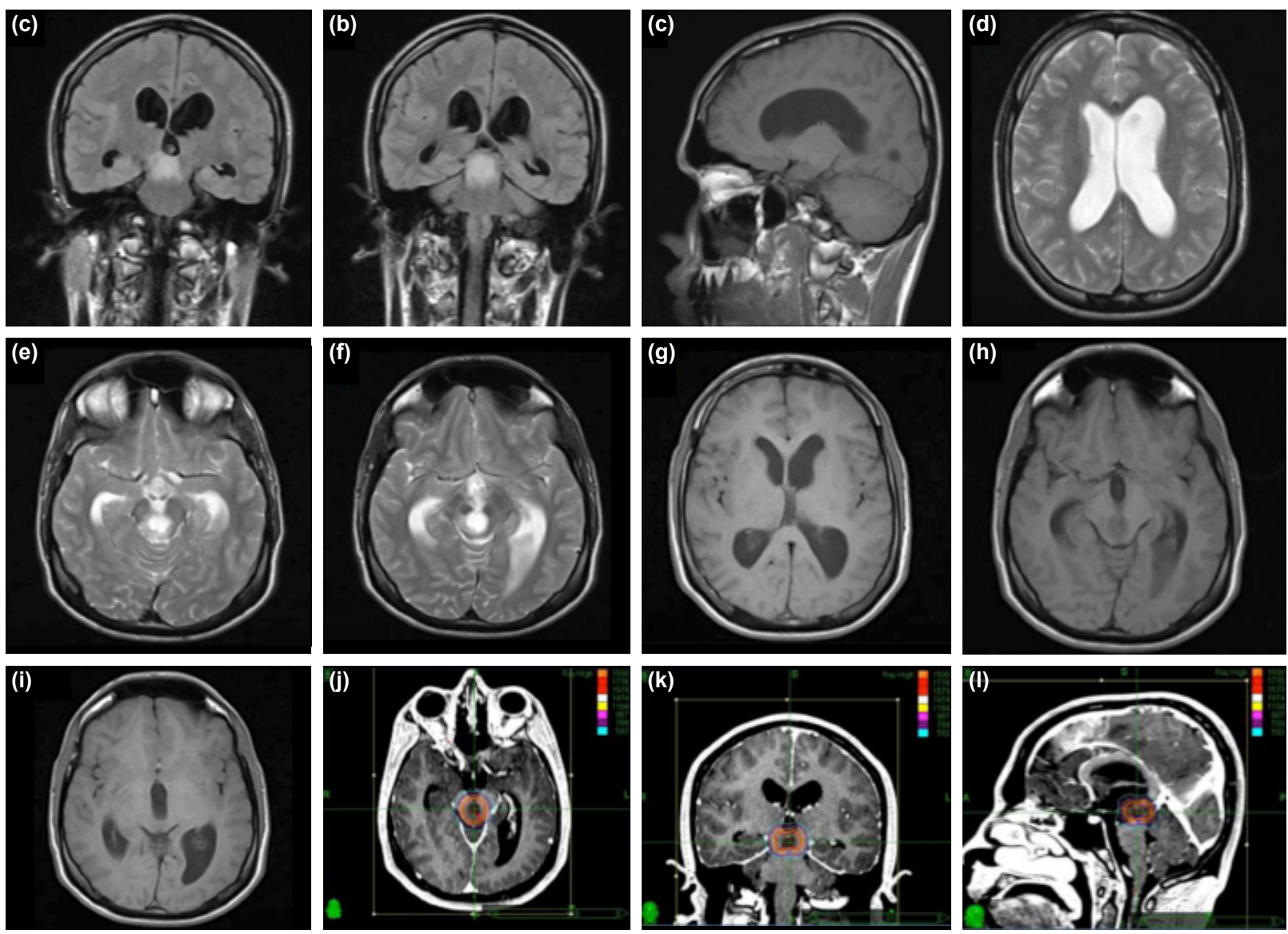

Figure 1. Magnetic resonance imaging 2 months after radiosurgery. Fluid-attenuated inversion recovery (a, b) images show mass lesion at the tectal region obstructing the third ventricle, and enlarged lateral and $3^{\text {rd }}$ ventricles can be seen in T2 (d-f), sagittal T1 (c), and axial T1 (g-i). Cyber-knife treatment plan of lesion for radiosurgery was shown on computerized tomography images (j-l). 
doscopic, open, and gamma knife treatments efficacy and outcomes reports mortality to be $10 \%$ in 40 patients who were all treated surgically. ${ }^{[6]}$ In 2013 , a 6-year-old girl was reported with treatment-refractory generalized and gelastic seizures due to $\mathrm{HH} .{ }^{[8]}$ Three months after gamma knife RS, she was admitted with an episode of drowsiness and a decreased level of consciousness (Glasgow Coma Scale of 12 el 3).$^{[8]}$ Brain MRI revealed an increase in the size of $\mathrm{HH}$ with adjacent edema. ${ }^{[8]}$ Dexamethasone achieved symptomatic improvement and a progressive decrease in the size of the lesion. ${ }^{[8]}$ Twelve months after surgery, complete disappearance of edema and hamartoma was observed. ${ }^{[8]}$ Our case is also the $4^{\text {th }}$ case of neurological symptoms secondary to non-necrotizing radio-induced inflammatory reaction after RS technique but is the first case with a lethal course.

RS protocols have been used in treatment guidelines with satisfactory results. Nevertheless, despite its low incidence, if a patients presents neurological symptoms, primarily during the first year after the intervention, possible complications of RS must be taken into account.

Informed Consent

Written informed consent was obtained from the patient for the publication of the case report and the accompanying images.

Peer-review

Internally peer-reviewed.

Authorship Contributions

Concept: G.Y., N.I.; Design: G.Y., N.I.; Data collection \&/ or processing: A.K.K., Ö.O.Ş.; Analysis and/or interpretation: G.Y., N.I.; Literature search: G.Y., N.I., A.K.K., Ö.O.Ş.;
Writing: A.K.K., Ö.O.Ş.; Critical review: G.Y., N.I.

Conflict of Interest

None declared.

\section{REFERENCES}

1. Coons SW, Rekate HL, Prenger EC, Wang N, Drees C, Ng YT, et al. The histopathology of hypothalamic hamartomas: study of 57 cases. J Neuropathol Exp Neurol 2007;66:131-41. [CrossRef]

2. Pati S, Sollman M, Fife TD, Ng YT. Diagnosis and management of epilepsy associated with hypothalamic hamartoma: an evidencebased systematic review. J Child Neurol 2013;28:909-16. [CrossRef]

3. McGonigal A, Sahgal A, De Salles A, Hayashi M, Levivier M, Ma L, et al. Radiosurgery for epilepsy: Systematic review and International Stereotactic Radiosurgery Society (ISRS) practice guideline. Epilepsy Res 2017;137:123-31. [CrossRef]

4. Mittal S, Mittal M, Montes JL, Farmer JP, Andermann F. Hypothalamic hamartomas. Part 1. Clinical, neuroimaging, and neurophysiological characteristics. Neurosurg Focus 2013;34:E6. [CrossRef]

5. Régis J, Lagmari M, Carron R, Hayashi M, McGonigal A, Daquin G, et al. Safety and efficacy of Gamma Knife radiosurgery in hypothalamic hamartomas with severe epilepsies: A prospective trial in 48 patients and review of the literature. Epilepsia 2017;58(Suppl 2):60-71. [CrossRef]

6. Drees C, Chapman K, Prenger E, Baxter L, Maganti R, Rekate H, et al. Seizure outcome and complications following hypothalamic hamartoma treatment in adults: endoscopic, open, and Gamma Knife procedures. J Neurosurg 2012;117:255-61. [CrossRef]

7. Régis J, Bartolomei F, de Toffol B, Genton P, Kobayashi T, Mori Y, et al. Gamma knife surgery for epilepsy related to hypothalamic hamartomas. Neurosurgery 2000;47:1343-51. [CrossRef]

8. O'Connor L, Curl-Roper T, Reeves N, Kemeny AA, Josan VA. Image-defined resolution following radiosurgery for hypothalamic hamartoma. J Neurosurg Pediatrics 2013;11:464-8. [CrossRef]

\section{CyberKnife Radyo Cerrahiyle Tedavi Edilen Bir Hipotalamik Hamartom Olgusunda Mortaliteye Neden Olan Bir Nörolojik Komplikasyon Örneği}

Hipotalamik hamartomlar epileptogenezde rolü olan ve çoğunlukla epileptik nöbetlerle kendini gösteren doğumsal anomalilerdir. Hipotalamik hamartomlarda sterotaktik radyocerrahi, mikrocerrahi rezeksiyon, endoskopik kopukluk, radyofrekans termokoagülasyon tedavi opsiyonlarıdır. Bu yazıda fatal seyreden CyberKnife ile tedavi edilmiş hipotalamik hamartom hastası sunuldu.

Anahtar Sözcükler: Epilepsi; hipotalamik hamartom; radyocerrahi. 